\title{
Perceived Occupational Hazards of Sanitary Inspectors from Two Urban Cities in the Philippines
}

\author{
Anne Clarisse C. Carlos, ${ }^{1}$ Rose Abigail D. Enoveso, ${ }^{1}$ Maria Lelis E. Palmares, ${ }^{1}$ \\ Lorra Angelia dC. Sayson, ${ }^{1}$ Kim Patrick S. Tejano ${ }^{1}$ and Gayline F. Manalang Jr. ${ }^{2}$ \\ ${ }^{1}$ Bachelor of Science in Public Health, College of Public Health, University of the Philippines Manila \\ ${ }^{2}$ Department of Environmental and Occupational Health, College of Public Health, University of the Philippines Manila
}

\begin{abstract}
Objective. This study aimed to describe the occupational hazards perceived by sanitary inspectors (SIs) from the City of Manila (Manila) and Quezon City (QC) as they perform their administrative and technical roles.

Methods. Hazards and control measures were identified using self-administered questionnaires distributed among Sls of Manila and QC from November to December 2010.

Results. The most frequently perceived hazards are slips, trips and falls, and verbal assault seen consistently present among 8 out of 9 roles. Harsh climatic condition on the other hand is the hazard perceived to be the riskiest as seen consistently in 8 out of 9 roles. Of the respondents, $28 \%$ did not receive formal training in the field of sanitary inspection and $64 \%$ did not have work shifts as administrative control measures; $90 \%$ said that personal protective equipment (PPE) were not made available to them and were not used by them.
\end{abstract}

Conclusion and Recommendations. The most frequently perceived hazards encountered by SIs are slips, trips and falls, harsh climatic conditions, unwarranted complaints, and verbal assault. On the other hand, harsh climatic conditions, unwarranted complaints, and slips, trips and falls are the occupational hazards which are consistently present and perceived to pose the most risk in more than five roles. Provision of PPE and improvement in the implementation of administrative control measures is recommended. Moreover, further studies involving SIs' actual experiences, SIs from rural areas and control measures present in the workplace are suggested.

Key Words: occupational hazards, sanitary inspectors, control measures, personal protective equipment

Corresponding author: Rose Abigail D. Enoveso

Department of Environmental and Occupational Health

College of Public Health

University of the Philippines Manila

625 Pedro Gil Street, Ermita, Manila 1000 Philippines

Telephone: +632 5247102 local 147

Email: abigail_enoveso@yahoo.com

\section{Introduction}

Sanitary inspectors (SIs) play a major role in public health as their responsibilities ensure the prevention and control of environmental health-related diseases. To fulfill this role, it is imperative that SIs be able to perform their tasks effectively and efficiently. The tasks of SIs in the Philippines may be classified as administrative and technical. Administrative roles include preparation of environmental sanitation programs, recording of environmental sanitation activities, establishing linkages with different communities and agencies; and, addressing complaints and field investigations. ${ }^{1}$ On the other hand, the activities pursued in relation to food and water sanitation, excreta and sewage and waste management, vermin control, public places sanitation, emergency sanitation and health education are classified under technical tasks. ${ }^{1,2}$

The broad scope of their tasks underscores their impact in improving and maintaining standards of health. As vital members of Philippine public health machinery, their successful performance of relevant duties and responsibilities towards compliance with sanitation and hygiene measures in the community influences the public's quality of life.

The Philippines, with a population of $87,000,000$ people, is only served by 3,000 SIs as reported in $2004 \mathrm{WHO}$ Country Report by the World Health Organization (WHO). This is below the WHO recommended 4,000 working SIs for the country, the estimated area coverage being 1 per 20,000 population. ${ }^{3}$ This unmet standard clearly indicates that the country is in dire need of SIs who will ensure that public health standards are observed. It is vital then that the safety and welfare of SIs be guaranteed as they perform their tasks.

SIs are assigned to different health districts per city. They are expected to perform their tasks in a variety of indoor and outdoor environments. Such duties and environments constantly expose them to certain types of hazards that may directly or indirectly impede the completion of their tasks, endanger their health and safety and consequently compromise their effectiveness in the public health system. According to the Department of Labor and Employment, the incidence rate of cases of non-fatal occupational injuries with lost workdays for the technical 
tasks of SIs such as sewage and refuse disposal, sanitation and similar activities recorded for the year 2003 is 9.89 per 1,000. There have been no reported fatal cases for this specific line of work. However, the non-fatal cases of occupational diseases leading to temporary incapacity with lost workdays sums up to 546 cases in 2009.4 Control measures-administrative, engineering and personal protective equipment (PPE)-also present a hazard when such are unavailable, not used and/or misused.

Essential to assuring safety and welfare of SIs is knowledge of their hazardous occupational exposures. The adequate set up of control and preventive measures to minimize the outcomes of hazards relies on this. The identification of hazards and their corresponding controls influences the competence and efficiency of SIs in promoting and maintaining public health.

This study aimed to describe the perceived occupational hazards of the SIs from the City of Manila and Quezon City as they perform their administrative and technical roles. Specifically, it determined the proportion of sanitary inspectors who perceive occupational hazards and the average score reported for each occupational hazard perceived. It also aimed to determine the proportion of sanitary inspectors who do not use available administrative control measures and PPE in performing their tasks.

This study did not set out to conduct a complete risk assessment of the SIs. Risks discussed in this paper are only implied according to the perception of the respondents. While administrative controls and PPE available were inquired, engineering control measures were not covered. These are best determined through ocular visits that could not be done by the researchers.

\section{Methods}

\section{Study Design}

The study used a cross-sectional descriptive study design. The occupational hazards, exposures, and control measures identified in the study were based on selfassessment of the participants and are all descriptive in nature.

\section{Study Population}

Sanitary inspectors employed from November to December 2010 in the City of Manila and Quezon City (QC),
National Capital Region of the Philippines were surveyed for the study and asked for their perceived occupational hazards as well as the control measures that they adhere to.

\section{Sampling Design and Size}

A list of all the sanitary inspectors employed in Manila and QC were obtained from the Sanitation Division of the respective city health offices. The list was used to determine the number of sanitary inspectors in both cities, as well as to contact the participants.

The sampling design used was stratified random sampling design where 66\% (65/98) came from Manila and $34 \%$ (33/98) from QC. Since there were no studies done in the past identifying the occupational hazards of SIs, health hazards of general working population was used in the computation. Using the formula for estimation of population proportion, in which the maximum error was set at 0.05, confidence level at 95\%, and knowing the highest proportion of workers exposed to the specific category of occupational hazard, the sample size was 382.78. But since the identified population size was 98 , the formula for sample size adjusted for population size was used, resulting to the final sample size of 78.04 or 78 . Knowing the sample size, stratified random sampling was utilized, where 51 participants will be coming from Manila City and the remaining 27 from Quezon City.

\section{Data Collection}

Data collection was done through a self-administered questionnaire (SAQ) adapted by the researchers from Health Assessment Hazard Questionnaire of the University of Melbourne. ${ }^{5}$ Entries were taken from the catalogued hazards of sanitarians as listed in the International Labour Organization (ILO) International Hazard Datasheets on Occupations alongside other reviewed literature on the different occupational hazards commonly associated with the tasks of SIs. Presented in Table 1 are the occupational hazards included in the ILO hazard datasheet for this occupation. ${ }^{6}$

Before finalizing the tool, a pre-test was conducted among SIs who took the 2010 National Sanitarian Training Course (NSTC) of the Department of Environmental and Occupational Health, College of Public Health, University of

Table 1. Occupational hazards which sanitary inspectors are exposed to according to International Labour Organization (ILO) International Hazard Datasheets on Occupation

\begin{tabular}{llll}
\hline \multicolumn{1}{c}{ ACCIDENT } & \multicolumn{1}{c}{ PHYSICAL } & \multicolumn{1}{c}{ CHEMICAL } & \multicolumn{1}{c}{ BIOLOGICAL } \\
\hline Slips, trips and falls & Excessive noise & Chronic poisoning due to & Microorganisms \\
Acute poisoning by (gases, & Ionizing radiation & exposure to various toxic & Bites and stings by \\
pesticides and others) & Non-ionizing radiation & materials & Verbal assaults \\
Burns & Extreme climatic & Contact with strong oxidants & Infectious diseases \\
Road accidents & conditions & Toxic gases present in sewage & while working in \\
Electrical shock & & and/or industries & resulting in psychological stress \\
Fires and explosions & & Dermatites and eczemas & \\
\hline
\end{tabular}


the Philippines Manila were consulted regarding the contents of the tool. Interviews with the President of the League of Sanitary Inspectors in the Philippines and the faculty coordinator of the NSTC program were also conducted to further enhance the tool.

\section{Data Collection Tool}

The questionnaire consisted of three parts: Demographics and Work Background, Perceived Occupational Hazard Determination and Control Identification. Table 2 outlines the content of the tool and the corresponding number of questions. In the second part of the questionnaire, each hazard is graded on a scale of 0-3 that denote level of risk from "no risk" to "high risk". The scale is given per item in the questionnaire and the respondent is asked to encircle their choice of answer depending on their perception. Hazards which were not perceived as a hazard present in their line of work or workplace ("no hazard") were left blank or were not encircled at all.

Table 2. Outline of the data collection tool used in the study

\begin{tabular}{|c|c|c|}
\hline & Content & $\begin{array}{l}\text { Number of } \\
\text { Questions }\end{array}$ \\
\hline I. & $\begin{array}{l}\text { Demographics and Work Background } \\
\text { - trainings regarding sanitary inspection } \\
\text { - duration in service } \\
\text { - current location of employment } \\
\text { - tasks done while in service }\end{array}$ & 4 \\
\hline \multirow[t]{3}{*}{ II. } & $\begin{array}{l}\text { Perceived Occupational Hazard Determination } \\
\text { A. Administrative Roles }\end{array}$ & \\
\hline & $\begin{array}{l}\text { - specific tasks performed } \\
\text { - occupational hazards perceived } \\
\text { - perceived risks of each occunational hazard }\end{array}$ & 3 \\
\hline & $\begin{array}{l}\text { B. Technical Roles } \\
\text { - specific tasks performed } \\
\text { - occupational hazards perceived } \\
\text { - perceived risks of each occupational hazard }\end{array}$ & 32 \\
\hline III. & $\begin{array}{l}\text { Control Identification } \\
\text { - practice of administrative control measures } \\
\text { - use of personal protective equipment }\end{array}$ & 2 \\
\hline
\end{tabular}

\section{Data Analysis}

Data gathered from the answers to the SAQ were coded prior to data processing and analysis. Alphanumeric codes were assigned in each item of the questionnaire and were used in encoding the data using Epi Info 2000 software. The output produced were the proportions of the sanitary inspectors who performed the different roles of SIs, proportions of SIs who perceived the hazards and the proportions of SIs who did not use control measures.

As for the determination of the level of risk entailed by each perceived hazard, analysis was done through computation of the means and standard deviation of the responses of the SIs per tasks.
Counts, proportions, means and standard deviation were used for the specific objectives of the study. The frequencies were generated to identify what hazards were considered as most frequently perceived. As for the means, the data were used to rank which hazards were considered to be the most risky. Data processing and encoding was done concurrently with data collection. Data analysis on the other hand was done after all the expected data have been collated.

\section{Ethical Considerations}

This study was pursued in fulfillment of the requirements for the degree Bachelor of Science in Public Health. The study protocol was reviewed and approved for implementation by the Special Studies Committee of the College of Public Health, University of the Philippines Manila. The committee is comprised of faculty who have undergone requisite research ethics training. The study utilized a questionnaire that required participation of the target population, the sanitary inspectors. To ensure voluntary and genuine involvement of the participants and to guarantee that no coercion will take place, informed consent was requested from each possible respondent.

Every participant has the right to privacy and confidentiality. It was made sure that all the pertinent information given by the participants were kept private and was only used for research purposes. Anonymity was observed for all the participants. Moreover, transparency in the proceedings in the research was observed; hence, the participants had the option to receive the information/result through a convenient and suitable medium they preferred.

\section{Results and Discussion}

\section{Background of the Respondents}

The sample size computed for the study was 78 . However, only 75 sanitary inspectors consented to join the study thus giving a response rate of $96.15 \%$. Out of 75 participants, 55 Sanitary Inspectors were from the City of Manila and the remaining 20 respondents were from Quezon City. With the exception of one respondent who failed to answer the questions on marital status and gender, 22 Sanitary Inspectors (29.33\%) are single, $45(60.00 \%)$ are married, and 7 (9.33\%) are widowed. Forty-three participants (57.33\%) are male and 32 participants $(42.67 \%)$ are female.

Two participants $(2.67 \%)$ failed to answer the question on educational background. Sixty-eight (68) participants (90.67\%) have college degree, 3 participants $(4.00 \%)$ have master's degree and 2 participants $(2.67 \%)$ have medical degrees. The undergraduate courses of sanitary inspectors are greatly varied comprising mainly of health sciences and 
social sciences, and are actually not necessarily related to sanitation or public health. According to the Head of Sanitation Division of the City of Manila Health Department, there should be an undergraduate program specifically tailored for SIs which is Bachelor of Applied Science in Environmental Sanitation. Based on an interview with $\mathrm{Mr}$. Clemente San Gabriel, the League of Sanitary Inspectors of the Philippines (LSIP) has also suggested this proposal.

Inquiries about the different trainings they have undergone were also made. All but six participants (8.00\%) answered the item regarding their training background. It was found out that 48 participants $(64.00 \%)$ have undergone the National Sanitarian Training Course (NSTC) or other trainings and seminars that are related to their work as sanitary inspectors. Twenty-one (21) participants $(28.00 \%)$ reported that they have not taken NSTC or any other trainings and seminars.

\section{Roles of the Respondents}

The roles of the sanitary inspectors are primarily divided into administrative and technical aspects. The technical roles are further subdivided into eight categories. ${ }^{1}$ Table 3 presents the basic tasks under each category adapted from the Operational Manual for Sanitary Inspectors. However, not all tasks were reported to be carried out by all the SIs. Administrative roles, water sanitation, and food sanitation are the tasks performed by 72 participants (96\%). Public places sanitation and health education are performed by $89.33 \%$ respondents. Emergency sanitation, vermin control and waste management were reported to be performed by $85.33 \%, 81.33 \%$ and $78.67 \%$ participants, respectively. Industrial hygiene, on the other hand, is the least performed task (73.33\%).

\section{Most Frequently Perceived Occupational Hazards}

Each role of SIs poses various occupational hazards. The researchers opt to present in this paper only the top three occupational hazards that were most frequently perceived and were perceived to pose the most risk. The following are the most frequently perceived hazards that were present in more than five roles: slips, trips and falls, harsh climatic conditions; unwarranted complaints; and verbal assault. Table 4 shows the proportion of the three most frequently perceived hazards in every task. Slips, trips and falls were consistently reported as the top one perceived hazard in performing six out of nine roles. In an interview with $\mathrm{Mr}$. San Gabriel of the LSIP, it was mentioned that their work requires them to visit and inspect various sites and settings that may have unleveled ground and unsteady paths, causing them to be unwary of the changing work settings. ${ }^{7}$
Table 3. Roles of sanitary inspectors in the Philippines and specific tasks involved

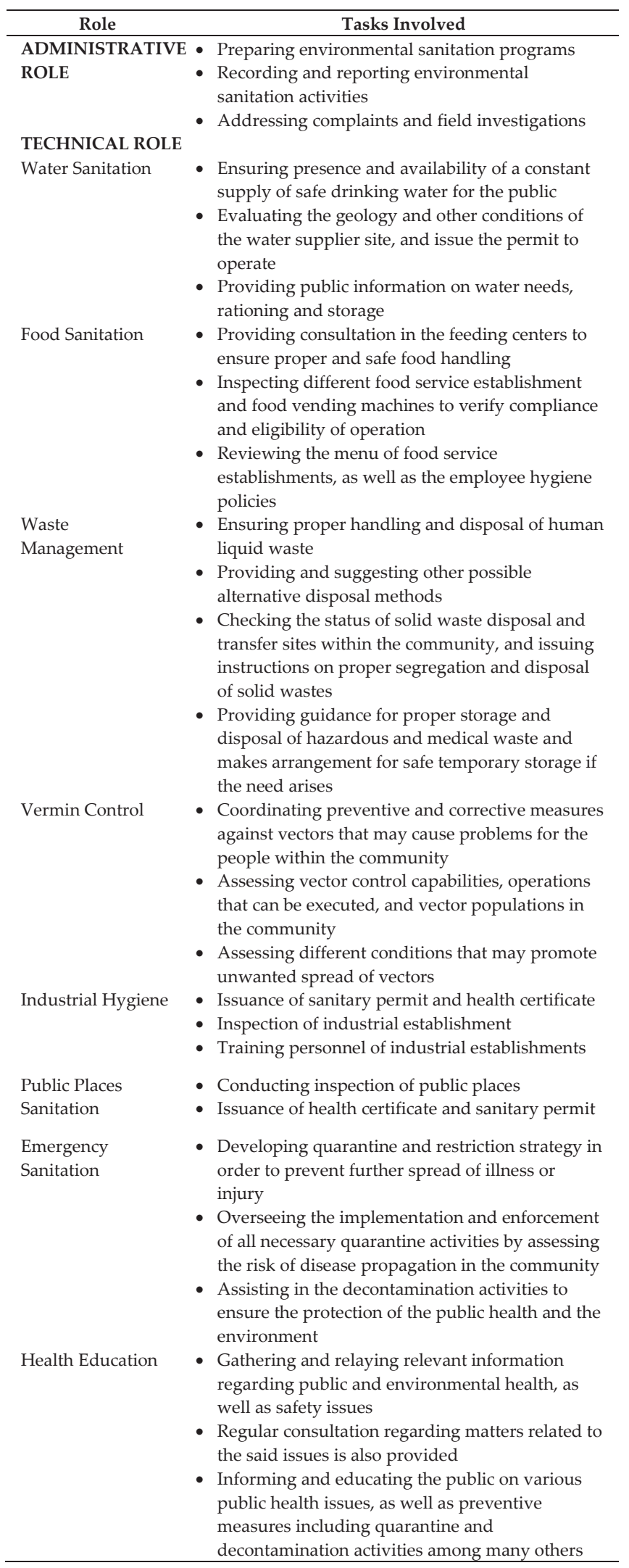


Table 4. Most frequently perceived occupational hazards in each task of Filipino sanitary inspectors

\begin{tabular}{|c|c|}
\hline Tasks & Most Frequently Perceived Occupational Hazards \\
\hline $\begin{array}{l}\text { Administrative } \\
(\mathrm{n}=72)\end{array}$ & $\begin{array}{c}\text { Slips, trips and falls }(98.61 \%) \\
\text { Verbal assault }(95.83 \%) \\
\text { Harsh climatic conditions }(94.44 \%)\end{array}$ \\
\hline Technical & \\
\hline $\begin{array}{l}\text { Water Sanitation } \\
(\mathrm{n}=72)\end{array}$ & $\begin{array}{c}\text { Verbal assault }(97.22 \%) \\
\text { Unwarranted complaints }(97.22 \%) \\
\text { Slips, trips and falls }(94.44 \%) \\
\text { Harsh climatic conditions }(94.44 \%)\end{array}$ \\
\hline $\begin{array}{l}\text { Food Sanitation } \\
(\mathrm{n}=72)\end{array}$ & $\begin{array}{c}\text { Slips, trips and falls }(97.22 \%) \\
\text { Verbal assault }(94.44 \%) \\
\text { Unsafe workplaces }(94.44 \%) \\
\text { Unwarranted complaints }(94.44 \%)\end{array}$ \\
\hline $\begin{array}{l}\text { Waste } \\
\text { management } \\
(\mathrm{n}=59)\end{array}$ & $\begin{array}{c}\text { Verbal assault }(94.92 \%) \\
\text { Unwarranted complaints }(94.92 \%) \\
\text { Microorganism }(93.22 \%) \\
\text { Slips, trips and falls }(93.22 \%)\end{array}$ \\
\hline $\begin{array}{l}\text { Vermin Control } \\
(\mathrm{n}=61)\end{array}$ & $\begin{array}{c}\text { Microorganism }(96.72 \%) \\
\text { Verbal assault }(95.08 \%) \\
\text { Unwarranted complaints }(93.44 \%)\end{array}$ \\
\hline Industrial & Slips, trips and falls (96.36\%) \\
\hline Hygiene $(n=55)$ & $\begin{array}{c}\text { Unsafe workplaces }(96.36 \%) \\
\text { Unwarranted complaints }(92.73 \%) \\
\text { Verbal assault }(92.73 \%)\end{array}$ \\
\hline Public Places & Slips, trips and falls (98.51\%) \\
\hline Sanitation $(\mathrm{n}=67)$ & $\begin{array}{c}\text { Verbal assault }(97.02 \%) \\
\text { Unsafe workplaces }(95.52 \%)\end{array}$ \\
\hline Emergency & Slips, trips and falls (96.88\%) \\
\hline Sanitation $(\mathrm{n}=64)$ & $\begin{array}{l}\text { Unsafe workplaces }(93.75 \%) \\
\text { Harsh climatic conditions }(92.17 \%)\end{array}$ \\
\hline $\begin{array}{l}\text { Health Education } \\
(\mathrm{n}=65)\end{array}$ & $\begin{array}{c}\text { Slips, trips and falls }(95.39 \%) \\
\text { Verbal assault }(90.77 \%) \\
\text { Unwarranted complaints }(90.77 \%) \\
\text { Unsafe workplaces }(90.77 \%)\end{array}$ \\
\hline
\end{tabular}

\section{Occupational Hazards Perceived to Pose the Most Risk}

Table 5 on the other hand shows the three occupational hazards perceived to pose the most risk in every role the respondents perform. Harsh climatic conditions, unwarranted complaints and slips, trips and falls are the occupational hazards which are consistently present and perceived to pose the most risk in more than five roles. In performing five roles, harsh climatic conditions appeared to be the hazard that was perceived to pose the most risk. Republic Act 6713 (Code of Conduct and Ethical Standards for Public Officials and Employees) states that public employees are obliged to comply with their duties within 15 calendar days even in such disagreeable weather conditions. ${ }^{8}$ In this study, the average risk score reported for each hazard perceived by the sanitary inspectors as they perform their administrative and technical roles were determined. Proportions, standard deviations, and means were computed for each perceived hazard across all roles (Appendix).
Table 5. Perceived occupational hazards with the highest risk scores in each task of Filipino sanitary inspectors

\begin{tabular}{lc}
\hline \multicolumn{1}{c}{ Tasks } & Perceived Occupational Hazards \\
\hline Administrative $(\mathrm{n}=72)$ & Harsh climatic conditions $(3.10 \pm 1.19)$ \\
& Unwarranted complaints $(2.82 \pm 1.19)$ \\
Technical & Verbal assault $(2.81 \pm 1.07)$ \\
Water Sanitation $(\mathrm{n}=72)$ & Harsh climatic conditions $(3.08 \pm 1.17)$ \\
& Unwarranted complaints $(2.94 \pm 1.07)$ \\
Food Sanitation $(\mathrm{n}=72)$ & Verbal assault $(2.90 \pm 1.07)$ \\
& Harsh climatic conditions $(2.89 \pm 1.27)$ \\
& Unwarranted complaints $(2.89 \pm 1.12)$ \\
Waste management $(\mathrm{n}=59)$ & Slips, trips and falls $(2.88 \pm 1.02)$ \\
& Microorganisms $(2.83 \pm 1.26)$ \\
& Toxic materials $(2.44 \pm 1.12)$ \\
Vermin Control $(\mathrm{n}=61)$ & Harsh climatic conditions $(2.59 \pm 1.43)$ \\
& Microorganisms $(2.89 \pm 1.08)$ \\
Industrial Hygiene $(\mathrm{n}=55)$ & Toxic materials $(2.77 \pm 1.44)$ \\
& Harsh climatic conditions $(2.72 \pm 1.30)$ \\
& Unwarranted complaints $(2.89 \pm 1.12)$ \\
Public Places Sanitation $(\mathrm{n}=67)$ & Slips, trips and falls $(2.78 \pm 1.03)$ \\
& Unsafe workplaces $(2.73 \pm 1.08)$ \\
& Slips, trips and falls $(2.84 \pm 0.95)$ \\
& Verbal assault $(2.79 \pm 1.07)$ \\
Emergency Sanitation $(\mathrm{n}=64)$ & Harsh climatic conditions $(2.75 \pm 1.32)$ \\
& Harsh climatic conditions $(2.89 \pm 1.26)$ \\
& Slips, trips and falls $(2.83 \pm 0.97)$ \\
Health Education $(\mathrm{n}=65)$ & Unsafe workplaces $(2.22 \pm 1.07)$ \\
& Harsh climatic conditions $(2.69 \pm 1.27)$ \\
& Slips, trips and falls $(2.55 \pm 1.08)$ \\
& Unwarranted complaints $(2.53 \pm 1.26)$ \\
\hline &
\end{tabular}

\section{Hazard Control Measures}

Because of the various occupational hazards that a sanitary inspector may encounter while working, hazard control measures should be practiced. ILO lists some of the commonly associated hazard controls with sanitary inspectors observing all recommended safety precautions as shown in Table 6. Given the requirements for hazard controls in the international setting, the same controls must be present for the sanitary inspectors in the Philippines. The various roles may require different sets of hazard controls but these control measures should neither be lacking or nonexistent. Incomplete or absent controls may present another hazard for the sanitary inspectors. Administrative control measures for sanitary inspectors involve the conduct of training as to the recognition and response to threat of violence and also the provision alarm or other means for summoning help. Among the administrative control measures, work shifts were the least implemented. Furthermore, around 90\% respondents reported that most personal protective equipment were not made available to and not used by them (Table 7). Gloves are the most widely used PPE by the SIs. Some data collection tools returned have comments stating that SIs were actually not provided with PPE. 
Table 6. Preventive measures for sanitary inspectors suggested by ILO

\begin{tabular}{l}
\hline \multicolumn{1}{c}{ Preventive measures } \\
\hline - Wear safety shoes with non-skid soles \\
- Observe all recommended safety precautions for entering a confined \\
space, including respiratory protection \\
- When spraying pesticides, of coming into contact with hazardous gases, \\
wear appropriate respiratory protection to avoid inhalation of aerosols \\
and dust \\
- Wear hearing protection appropriate for the noise levels and type of \\
noise \\
- Check radiation level before approaching radiation sources and wear \\
personal radiatioin dosimeter \\
- Use safety glasses with UV-shielded lenses when potential exposure to \\
- Protect hands with chemical-resistant gloves, if impractical use barrier \\
cream \\
- Train employees how to recognize and respond to threat of violence; \\
provide alarm or other means for summoning help, or escort if needed. \\
\hline
\end{tabular}

Table 7. Proportion of Filipino sanitary inspectors who do not observe control measures

\begin{tabular}{lc}
\hline Control Measures & Proportion (\%) \\
\hline Administrative Control Measures & 64 \\
Work shifts & 48 \\
Job rotations & 36 \\
Provided policies and protocols & 26 \\
Training & \\
Personal Protective Equipment & 97 \\
Face shields & 98 \\
Vest, jackets and coats & 96 \\
Hats & 96 \\
Glasses/goggles & 91 \\
Safety shoes, boots & 87 \\
Dust masks & 83 \\
Gloves & \\
\hline
\end{tabular}

\section{Conclusion and Recommendations}

Sanitary inspectors persevere to meet the health-related needs of the community. As they are constantly exposed to certain types of occupational hazards in their workplaces, their health and safety are endangered; and therefore may compromise the public's interest. Respondents of this study report that among the roles of SIs, the administrative role entails the most number of perceived occupational hazards while the role which has the least number of perceived occupational hazards is health education. Among all the occupational hazards of the SIs, slips, trips and falls are the most frequently perceived hazards while harsh climatic condition is the occupational hazard perceived to pose the highest risk.

In both urban Philippine cities covered in this study, administrative controls are implemented, such as provision of trainings, policies and protocols for safety conduct of tasks, work shifts, rests or breaks and job rotations. However, among these control measures, work shifts are the least implemented, being practiced only by less than half of the SIs surveyed. While working in shifts is a recommended control measure, there may be differences in work practice hence it is not observed across all those surveyed. These practice differences were not investigated in the study and would be useful in determining appropriate administrative measures.

Personal protective equipment is not consistently provided among the respondents. Some standards require that employers provide PPE at no cost to the employee while others simply state that the employer must provide PPE. ${ }^{9}$ Based on the Philippine Occupational Safety and Health Standards (POSHS), every employer shall at his own expense furnish his workers with protective equipment. Furthermore, the employer shall be responsible for the adequacy and proper maintenance of personal protective equipment used in his workplace. ${ }^{10}$ This local standard is intended mainly for manufacturing industries. However, the results of this study indicated that only a low fraction of SIs is equipped with PPE by their employers. The limited availability of PPE is possibly due to lack of specific guiding instruments such as the POSHS for SIs. In line with this, it is recommended that SIs must be provided with PPE as well as defined guiding instruments by their city health department. This might strengthen the enforcement of rules regarding PPE and encourage SIs to use PPE more frequently. It is also recommended that a policy upholding the safety of SIs from occupational hazards and other threats to their health be established.

This study did not include engineering control measures. It also focused only on the perception of the SIs and those only in urban cities. Hence, further studies on the SIs which include engineering controls are recommended. Studies focusing on SIs actual experiences are also suggested. Such studies will validate the results of the study and will further address the occupational hazards of SIs. Lastly, further verification on the tasks and roles performed by the SIs and possible delineations in the set-ups entailing different occupational hazards between the sanitary inspectors working in the urban from those working in the rural areas is encouraged.

\section{References}

1. University of the Philippines Manila, College of Public Health, Department of Environment and Occupational Health. Operational manual for sanitary inspectors. Manila: Department of Environment and Occupational Health; 1970.

2. Powitz R. Role of local health department sanitarian [Online]. Misssouri: Saint Louis University; 2004 [cited 2011 Apr]. Available from bioterrorism.slu.edu/bt/education/Sanitarian.doc

3. World Health Organization. Water and sanitation country profile for the Philippines. Manila: World Health Organization; 2005.

4. Department of Labor and Employment, Bureau of Labor and Employment Statistics. Occupational Diseases [Online]. Philippine Industry Yearbook of Labor Statistics 2009 [cited 2011 Jan]. Available from http://bles.dole.gov.ph/2009\%20

Publications/PIYB/Occupational\%20Diseases/OD-1994\%20coverage.htm

5. University of Melbourne. Health assessment hazard questionnaire [Online] Melbourne: University of Melbourne; 2009 [cited 2011 Apr]. Available from safety.unimelb.edu.au/docs/HR15.doc

6. International Labour Organization. International hazards datasheets on occupation [Online]. Geneva, Switzerland: International Labour Organization. 1999 [modified 2000 May; cited 2011 Apr]. Available from http://www.ilo.org/wcmsp5/groups/public/---ed_protect/---protrav/--safework/documents/publication/wcms_191024.pdf 
7. Environment Protection Agency. Health and safety hazards for site inspectors [Online]. New South Wales: Environment Protection Agency; 2007 [modified 2013 June; cited 2011 Apr]. Available from http://www.epa.nsw.gov.au/mao/healthsafetyhazards.htm

8. Republic Act No. 6713. "Code of Conduct and Ethical Standards for Public Officials and Employees. Approved 1989 February 20. Effective 1989 March 25.
9. U.S. Department of Labor, Occupational Safety and Health Administration. Personal Protective Equipment [Online]. Washington DC; 2003 [cited 2011 Apr]. Available from https://www.osha.gov/Publications/osha3151.html

10. Department of Labor and Employment, Occupational Safety and Health Center. Occupational Safety and Health Standards (as amended 1989). Rule 1080: Personal Protective Equipment and Devices. Intramuros, Manila; 1989.

\section{Appendix}

\begin{tabular}{|c|c|c|c|c|c|c|c|c|c|c|c|}
\hline \multirow[b]{2}{*}{$\begin{array}{c}\text { Perceived } \\
\text { Hazards }\end{array}$} & \multirow{2}{*}{\multicolumn{2}{|c|}{ Administrative Role }} & \multicolumn{9}{|c|}{ Technical Roles } \\
\hline & & & $\begin{array}{c}\text { Emergency } \\
\text { Sanitation }\end{array}$ & $\begin{array}{c}\text { Food } \\
\text { Sanitation }\end{array}$ & $\begin{array}{l}\text { Industrial } \\
\text { Hygiene }\end{array}$ & $\begin{array}{c}\text { Public } \\
\text { Health } \\
\text { Education }\end{array}$ & $\begin{array}{c}\text { Excreta } \\
\text { Management }\end{array}$ & $\begin{array}{l}\text { Public Places } \\
\text { Sanitation }\end{array}$ & $\begin{array}{l}\text { Solid Waste } \\
\text { Management }\end{array}$ & $\begin{array}{l}\text { Vermin } \\
\text { Control }\end{array}$ & $\begin{array}{c}\text { Water } \\
\text { Supply } \\
\text { Sanitation }\end{array}$ \\
\hline \multirow{3}{*}{$\begin{array}{l}\text { Driving } \\
\text { Hazard }\end{array}$} & Prop (\%) & 87.50 & 75.00 & 80.56 & 76.36 & 75.39 & 74.58 & 77.61 & 77.94 & 72.13 & 86.11 \\
\hline & Mean & 2.0694 & 1.8281 & 2.000 & 1.9818 & 1.7077 & 1.745 & 1.806 & 1.8529 & 1.6557 & 2.0278 \\
\hline & $\mathrm{SD}$ & 1.2596 & 1.3634 & 1.3531 & 1.5091 & 1.2836 & 1.334 & 1.3398 & 1.3633 & 1.3526 & 1.2215 \\
\hline \multirow{3}{*}{$\begin{array}{c}\text { Electricity } \\
\text { Hazard }\end{array}$} & Prop (\%) & 83.33 & 71.88 & 81.94 & 81.80 & 75.39 & 74.58 & 75.12 & 80.88 & 68.85 & 81.94 \\
\hline & Mean & 2.1111 & 2.0156 & 2.2361 & 2.2727 & 1.9385 & 1.932 & 1.9552 & 2.1324 & 1.7705 & 2.25 \\
\hline & $\mathrm{SD}$ & 1.4197 & 1.5378 & 1.4486 & 1.3805 & 1.4883 & 1.472 & 1.44 & 1.4342 & 1.5318 & 1.4511 \\
\hline \multirow{3}{*}{$\begin{array}{c}\text { Excessive } \\
\text { Noise }\end{array}$} & Prop (\%) & 78.13 & 78.13 & 81.94 & 81.80 & 80.00 & 79.66 & 86.57 & 86.76 & 78.69 & 88.89 \\
\hline & Mean & 2.4167 & 2.1406 & 2.1944 & 2.2727 & 2.0462 & 2.186 & 2.2836 & 2.3088 & 2.082 & 2.4722 \\
\hline & SD & 1.1101 & 1.4014 & 1.3389 & 1.367 & 1.3513 & 1.42 & 1.2769 & 1.2843 & 1.394 & 1.2444 \\
\hline \multirow{3}{*}{$\begin{array}{c}\text { Harmful by } \\
\text { products }\end{array}$} & Prop (\%) & 68.10 & 78.125 & 87.50 & 89.09 & 78.46 & 84.75 & 86.57 & 86.76 & 80.33 & 88.89 \\
\hline & Mean & 2.4444 & 2.2188 & 2.3333 & 2.5818 & 2.0769 & 2.457 & 2.2985 & 2.4706 & 2.3607 & 2.5972 \\
\hline & SD & 1.4427 & 1.4743 & 1.3738 & 1.329 & 1.4286 & 1.394 & 1.2769 & 1.398 & 1.4948 & 1.2744 \\
\hline \multirow{3}{*}{$\begin{array}{c}\text { Harsh Climatic } \\
\text { Conditions }\end{array}$} & Prop (\%) & 94.44 & 92.19 & 90.28 & 90.91 & 89.23 & 86.44 & 89.56 & 91.18 & 88.52 & 94.44 \\
\hline & Mean & 3.0972 & 2.8906 & 2.8889 & 2.6545 & 2.6923 & 2.593 & 2.7463 & 2.7794 & 2.7167 & 3.0833 \\
\hline & SD & 1.1887 & 1.2614 & 1.2733 & 1.2797 & 1.2738 & 1.427 & 1.3182 & 1.2795 & 1.3031 & 1.1719 \\
\hline \multirow{3}{*}{$\begin{array}{c}\text { High } \\
\text { Temperature }\end{array}$} & Prop (\%) & 87.50 & 76.56 & 87.50 & 78.18 & 70.77 & 81.36 & 79.10 & 86.76 & 78.69 & 80.56 \\
\hline & Mean & 2.1667 & 2.0625 & 2.4583 & 2.0727 & 1.8 & 2.085 & 2.0149 & 2.2941 & 2.0328 & 2.0972 \\
\hline & $\mathrm{SD}$ & 1.3108 & 1.4461 & 1.2885 & 1.4123 & 1.4491 & 1.343 & 1.3651 & 1.2585 & 1.378 & 1.3856 \\
\hline \multirow{3}{*}{$\begin{array}{c}\text { Ionizing } \\
\text { Radiation }\end{array}$} & Prop (\%) & 80.56 & 64.06 & 72.22 & 72.73 & 66.15 & 69.49 & 73.13 & 70.59 & 65.57 & 75.00 \\
\hline & Mean & 2.0278 & 1.6094 & 1.8333 & 2.0545 & 1.6 & 1.694 & 1.8955 & 1.7941 & 1.623 & 2.0278 \\
\hline & SD & 1.5103 & 1.4579 & 1.5012 & 1.5566 & 1.4874 & 1.465 & 1.3651 & 1.4818 & 1.5074 & 1.5196 \\
\hline \multirow{3}{*}{$\begin{array}{l}\text { Non Ionizing } \\
\text { radiation }\end{array}$} & Prop (\%) & 80.56 & 65.63 & 72.22 & 85.46 & 66.15 & 67.80 & 71.64 & 73.53 & 65.57 & 75.00 \\
\hline & Mean & 1.8889 & 1.5938 & 1.8611 & 1.9273 & 1.5538 & 1.694 & 1.7164 & 1.7353 & 1.5574 & 1.7639 \\
\hline & SD & 1.3061 & 1.3884 & 1.4757 & 1.4123 & 1.381 & 1.465 & 1.3905 & 1.3888 & 1.3967 & 1.3479 \\
\hline \multirow{3}{*}{$\begin{array}{l}\text { Oils and } \\
\text { Solvents }\end{array}$} & Prop (\%) & 84.72 & 71.88 & 73.61 & 80.00 & 72.31 & 74.58 & 80.60 & 77.94 & 77.05 & 77.78 \\
\hline & Mean & 2.2778 & 2.0313 & 1.9722 & 2.3455 & 1.8615 & 2.051 & 2.1791 & 2.1471 & 2.4262 & 1.9583 \\
\hline & SD & 1.345 & 1.5324 & 1.5196 & 1.4934 & 1.4564 & 1.491 & 1.4241 & 1.4483 & 1.5541 & 1.4086 \\
\hline \multirow{3}{*}{$\begin{array}{l}\text { Pathogenic } \\
\text { Organisms }\end{array}$} & Prop (\%) & 86.11 & 84.38 & 84.72 & 89.09 & 81.54 & 93.22 & 89.55 & 91.18 & 96.72 & 86.11 \\
\hline & Mean & 2.4722 & 2.5938 & 2.4444 & 2.5818 & 2.2769 & 2.831 & 2.597 & 2.6618 & 2.8852 & 2.4583 \\
\hline & $\mathrm{SD}$ & 1.3319 & 1.3998 & 1.423 & 1.315 & 1.4417 & 1.262 & 1.2439 & 1.2884 & 1.0816 & 1.342 \\
\hline \multirow{3}{*}{$\begin{array}{c}\text { Physical } \\
\text { Assault }\end{array}$} & Prop (\%) & 87.50 & 89.06 & 88.69 & 90.91 & 89.23 & 88.14 & 92.54 & 89.71 & 90.16 & 91.67 \\
\hline & Mean & 2.2958 & 2.431 & 2.4028 & 2.4 & 2.3231 & 2.356 & 2.4179 & 2.3824 & 2.3443 & 2.4861 \\
\hline & SD & 1.2806 & 1.3205 & 1.2855 & 1.2413 & 1.3359 & 1.361 & 1.2439 & 1.3274 & 1.3277 & 1.2559 \\
\hline \multirow{3}{*}{$\begin{array}{l}\text { Slips, Trips } \\
\text { and Falls }\end{array}$} & Prop (\%) & 98.61 & 96.88 & 97.22 & 96.36 & 95.39 & 93.22 & 98.51 & 98.53 & 90.16 & 94.44 \\
\hline & Mean & 2.6389 & 2.8281 & 2.875 & 2.7818 & 2.5538 & 2.593 & 2.8358 & 2.8529 & 2.5574 & 2.7917 \\
\hline & SD & 0.9686 & 0.9686 & 1.02 & 1.0308 & 1.0757 & 1.116 & 0.947 & .09661 & 1.2183 & 0.9335 \\
\hline & Prop (\%) & 84.72 & 73.44 & 83.33 & 85.46 & 72.31 & 79.66 & 82.09 & 77.94 & 77.05 & 87.50 \\
\hline strong & Mean & 2.25 & 2.0313 & 2.25 & 2.4545 & 1.9538 & 2.22 & 2.2687 & 2.2059 & 2.2459 & 2.375 \\
\hline & SD & 1.3295 & 1.4797 & 1.3712 & 1.3446 & 1.5148 & 1.463 & 1.3771 & 1.4818 & 1.5347 & 1.272 \\
\hline & Prop (\%) & 84.72 & 76.56 & 80.56 & 83.64 & 70.77 & 77.97 & 83.58 & 79.41 & 78.69 & 81.94 \\
\hline Toxic Gases & Mean & 2.4722 & 2.2188 & 2.3196 & 2.6182 & 1.9385 & 2.305 & 2.3881 & 2.3824 & 2.5574 & 2.4028 \\
\hline & SD & 1.4337 & 1.4957 & 1.5089 & 1.4718 & 1.57 & 1.545 & 1.4244 & 1.5262 & 1.5655 & 1.4791 \\
\hline & Prop (\%) & 81.94 & 78.13 & 83.33 & 83.64 & 73.85 & 81.36 & 83.58 & 85.29 & 85.25 & 80.56 \\
\hline $\begin{array}{l}10 x i c \\
\text { Materials }\end{array}$ & Mean & 2.4167 & 2.3438 & 2.2222 & 2.5273 & 1.9846 & 2.441 & 2.4179 & 2.4412 & 2.7705 & 2.0972 \\
\hline & SD & 1.5082 & 1.493 & 1.3964 & 1.4638 & 1.5257 & 1.489 & 1.4158 & 1.4182 & 1.4421 & 1.3856 \\
\hline & Prop (\%) & 93.06 & 93.75 & 94.44 & 96.36 & 90.77 & 91.53 & 95.52 & 95.59 & 91.80 & 93.06 \\
\hline Worknlaces & Mean & 2.5417 & 2.2188 & 2.6806 & 2.7273 & 2.3692 & 2.509 & 2.6418 & 2.7647 & 2.5246 & 2.7222 \\
\hline & $\mathrm{SD}$ & 1.2553 & 1.069 & 1.1111 & 1.0793 & 1.1668 & 1.165 & 1.0106 & 1.1213 & 1.149 & 1.1287 \\
\hline & Prop (\%) & 94.44 & 90.65 & 94.44 & 92.73 & 90.77 & 94.92 & 92.54 & 95.59 & 93.44 & 97.22 \\
\hline Complaints & Mean & 2.8194 & 2.6563 & 2.8889 & 2.7455 & 2.5385 & 2.831 & 2.6866 & 2.7647 & 2.6885 & 2.9444 \\
\hline & SD & 1.1906 & 1.25 & 1.1203 & 1.1897 & 1.2634 & 1.132 & 1.1574 & 1.0806 & 1.1625 & 1.0732 \\
\hline & Prop (\%) & 95.83 & 90.63 & 94.44 & 92.73 & 90.77 & 94.92 & 97.02 & 95.59 & 95.08 & 97.22 \\
\hline Verbal Assault & Mean & 2.8056 & 2.625 & 2.8472 & 2.6364 & 2.5231 & 2.763 & 2.791 & 2.6765 & 2.6066 & 2.9028 \\
\hline & SD & 1.0699 & 1.2662 & 1.1827 & 1.1764 & 1.2004 & 1.94 & 1.0665 & 1.1256 & 1.2011 & 1.0768 \\
\hline
\end{tabular}

